\title{
PDGFRB Gene Amplification
}

National Cancer Institute

\section{Source}

National Cancer Institute. PDGFRB Gene Amplification. NCI Thesaurus. Code C129619.

A molecular genetic abnormality indicating the presence of multiple copies of the PDGFRB gene. 